Nr 1(64), 2020, s. 357-374

https://doi.org/10.12797/Politeja.17.2020.64.18

Katarzyna BRZOZA-KOLORZ iD

Uniwersytet Śląski w Katowicach

katarzyna.brzoza@us.edu.pl

\title{
RAMA KONFLIKTU W OPISIE MEDIÓW \\ MASOWYCH I POLITYKI W OKRESIE \\ POLSKIEJ KAMPANII PARLAMENTARNEJ 2015 W WYBRANYCH TYGODNIKACH OPINII ${ }^{1}$
}

ABSTRACT Conflict Frame in the Description of Mass Media and Politics during the Polish Parliamentary Campaign 2015 in Selected Opinion Weekly

The article presents the results of the content analysis of selected copies from four opinion weekly publications, namely "Polityka", "Wprost", "Newsweek Polska”, and "Do Rzeczy", published during the Polish parliamentary campaign in 2015. The aim of the analysis was to show how the editors build the conflict frame by describing the relationship between mass media and politics and what elements are utilized to construct the analytical frame.

Key words: conflict frame, framing, mass media, politics, content analysis

Słowa kluczowe: rama konfliktu, ramowanie, mass media, polityka, analiza zawartości

Artykuł powstał w ramach projektu badawczego pt.: Powiąania pomiędzy elitami sfery mediów i polityki w Polsce w perspektywie doświadczeń niemieckich, realizowanego z funduszy Narodowego Centrum Nauki, konkurs OPUS 10, umowa nr UMO-2015/19/B/HS5/00429. 


\section{KONFLIKT JAKO ELEMENT TEORETYCZNYCH ROZWAŻAŃ MEDIOZNAWCZYCH}

Ralph Negrine postrzega procesy komunikowania politycznego przez pryzmat zawartości mediów masowych. Zwraca uwagę na fakt, iż w ich zróżnicowanej zawartości odbijają się stosunki między nimi a najważniejszymi aktorami politycznymi i przedstawianymi przez nie wydarzeniami. Według niego w sposobie prezentowania wydarzeń medialnych można dostrzec stopień podporządkowania mediów politycznym aktorom².

Powiązania między światem mass mediów i polityki są szczególnie widoczne w okresie kampanii wyborczych, będących wyjątkowym momentem dla każdej demokracji liberalnej. Związki te mogą przybierać różne formy. Ulrich Sarcinelli wskazał trzy modele relacji media-polityka: 1) paradygmat udziału we władzy (media jako czwarta władza są instytucją kontrolną wobec władzy legislacyjnej, wykonawczej i sądowniczej), 2) paradygmat instrumentalizacji (system medialny dominuje nad systemem politycznym albo odwrotnie), 3) paradygmat niezależności i symbiozy (media i polityka wzajemnie od siebie zależą i dlatego dochodzi do stałych interakcji $)^{3}$. Eksponowany w artykule konflikt wpisuje się w paradygmat instrumentalizacji i pojawia się w modelu adwersarzy, opartym na założeniu, że dziennikarze muszą postrzegać polityków i ważne postaci z kręgów rządowych jako swoich przeciwników, na usługach których nigdy nie powinni się znaleźć. Akceptowanym modelem działania są tutaj konfrontacja i wzajemne ataki dwóch stron, które mogą mieć formę ukrytą lub jawną, a nawet prowadzić do wyraźnych przejawów wrogości ${ }^{4}$.

Pojęcie framing w postaci tzw. ram zostało przeniesione na grunt analiz medioznawczych w latach 70. XX w., kiedy badacze odeszli od jednowymiarowego modelu efektów medialnych i zaczęli się zajmować konkretnymi formami wpływu mass mediów na odbiorców5. O ile teoria agenda-setting wyznacza, na co powinien zwrócić uwagę odbiorca, o tyle ramy (frames) pokazują, jak powinien myśleć o tym, co pojawia się w medialnym przekazie. Michael Kunczik i Astrid Zipfel traktują framing (uramowienie) jako ramy interpretacyjne wykorzystywane przez dziennikarzy, mające wpływ na to, które wydarzenia w ogóle są relacjonowane, natomiast cechy wydarzeń określają, jakie schematy interpretacyjne zastosują dziennikarze. Właśnie ten element będzie uwzględniony w analizie zawartości przeprowadzonej na potrzeby niniejszego artykułu ${ }^{6}$.

2 B. Dobek-Ostrowska, Komunikowanie polityczne i publiczne. Podręcznik akademicki, Warszawa 2012, s. 144-146.

3 S. Michalczyk, Demokracja medialna. Teoretyczna analiza problemu, Torun 2010, s. 73.

4 B. Dobek-Ostrowska, Media masowe i aktorzy polityczni w świetle studiów nad komunikowaniem politycznym, Wrocław 2004, s. 211-212, Acta Universitatis Wratislaviensis, nr 2594.

5 I. Volkmer, Framing Theory, [w:] Encyclopedia of Communication Theory, red. S.W. Littlejohn, K.A. Foss, Los Angeles 2009, s. 408.

6 M. Kunczik. A. Zipfel, Wprowadzenie do nauki o dziennikarstwie i komunikowaniu, przeł. J. Łoziński, W. Łukowski, Warszawa 2000, s. 125-126. 
Oczywiście w medialnych newsach można poszukiwać wielu ram interpretacyjnych, ale badacze - m.in.: Holli Semetko i Patti M. Valkenburg, Ewa Nowak i Rafał Riedel, Wojciech Cwalina i Andrzej Falkowski, Marek Palczewski ${ }^{7}$ - najczęściej odwołują się do klasyfikacji, która przewiduje podział na pięć ram interpretacyjnych: koncentracji na człowieku, moralności, odpowiedzialności, konfliktu i konsekwencji ekonomicznych ${ }^{8}$. Należy podkreślić, iż wielu badaczy szczególnie akcentuje ramę konfliktu (conflict frame), czyli schemat prezentowania wydarzeń ujmowanych w kategoriach sporu, niezgody, różnic trudnych do pogodzenia, kontrowersji. Ekspozycja sytuacji negatywnych w dobie tabloidyzujących się mass mediów jest nagminnym działaniem, a szokujące newsy mają przyciągnąć uwagę potencjalnego odbiorcy. Rama konfliktu według Claesa H. de Vreesego podkreśla konflikt między jednostkami, grupami, instytucjami lub krajami ${ }^{9}$, a jej charakterystyce służą takie elementy, jak polaryzacja sił, polityczne współzawodnictwo, medialna interpretacja świata polityki jako serii walk, w której wskazuje się zwycięzców i pokonanych ${ }^{10}$. A czymże jest kampania wyborcza, jak nie przykładem politycznej potyczki, okresem szczególnej rywalizacji, która kończy się przy urnie wyborczej, wskazaniem wygranych i pokonanych?

Dorota Piontek także zauważyła, że w grupie najpopularniejszych sposobów ramowania wydarzeń relacjonowanych przez media w koncepcji framingu Roberta M. Entmana pojawia się wydarzenie jako konflikt, czyli relacja skupiająca się na niezgodzie, podziale i różnicach oraz rywalizacji. W taki sposób są często przedstawiane wydarzenia polityczne, zwłaszcza w okresie kampanii wyborczej. Słowa i obrazy budujące ramy dają się dość łatwo wyróżnić z pozostałych informacji, gdyż mają zdolność stymulowania poparcia bądź opozycji wobec stron politycznego konfliktu ${ }^{11}$.

Zdaniem Williama A. Gamsona i Andre Modiglianiego metafory są jednym z elementów rozpoznawania ram $^{12}$, a dyskurs polityczny w okresie kampanii wyborczej jest przepełniony metaforyką wojenną, charakterystyczną dla ramy konfliktu ${ }^{13}$. Dlatego

H.A. Semetko, P.M. Valkenburg, Framing European Politics: A Content Analysis of Press and Television News, "Journal of Communication” 2000, Vol. 50, nr 2, s. 93-109; E. Nowak, R. Riedel, Agenda setting, priming, news framing. Analiza porównawcza telewizyjnych audycji informacyjnych TVN $i$ TVP1 w okresie kampanii przedwyborczych w Polsce 2005 i 2007, „Zeszyty Prasoznawcze” 2008, nr 1-2, s. 6783; W. Cwalina, A. Falkowski, Marketing polityczny. Perspektywa psychologiczna, Gdańsk 2005, s. 273 275, Psychologia Polityczna; M. Palczewski, Koncepcja framingu i jej zastosowanie w badaniach newsów $w$ Wiadomościach TVP i Faktach TVN, „Studia Medioznawcze” 2011, nr 1, s. 31-41.

8 W.R. Neuman, M. Just, A.N. Crigler, Common Knowledge. News and the Construction of Political Meaning, Chicago 1992, s. 60 i n., American Politics and Political Economy Series.

9 C.H. de Vreese, News Framing: Theory and Typology, „Information Design Journal \& Document Design" 2005, Vol. 13, nr 1, s. 56.

10 Cyt. za: M. Palczewski, Koncepcja framingu..., s. 34.

11 D. Piontek, Komunikowanie polityczne i kultura popularna. Tabloidyzacja informacji o polityce, Poznań 2011, s. 73.

12 W.A. Gamson, A. Modigliani, Media Discourse and Public Opinion on Nuclear Power: A Constructionist Approach, „American Journal of Sociology” 1989, Vol. 95, nr 1, s. 1-37.

13 W. Cwalina, A. Falkowski, Marketing polityczny..., s. 274. 
analiza ramy konfliktu w publikacjach tygodników opinii w okresie parlamentarnej kampanii wyborczej jest w pełni uzasadniona.

Hans Mathias Kepplinger pisze o teorii aktualizacji instrumentalnej, która ma zastosowanie w przypadku konfliktów publicystycznych; niektóre media oraz część publiczności zajmują wówczas stanowiska adwersarzy w jakiejś kontrowersyjnej kwestii. To zasada, zgodnie z którą fakty, tematy, argumenty powiązane z przedmiotem konfliktu są sytuowane na pierwszym planie. W celu pokazania w dobrym świetle swoich poglądów i zdyskredytowania opozycyjnej opinii dochodzi do świadomego i celowego zmniejszania znaczenia pewnych faktów i ekspozycji innych. Dziennikarze, zwłaszcza mediów opiniotwórczych, mogą stać się stroną w sporze. Na prezentowane przez nich treści mogą oddziaływać ich osobiste przekonania i poglądy, wpływające na dobór i sposób ukazywania faktów czy wydarzeń. Podobnie preferencje mediów mogą być znaczące i widoczne, zwłaszcza w tak istotnych momentach, jak czas kampanii wyborczej ${ }^{14}$.

\section{METODOLOGIA BADAŃ WŁASNYCH I WYNIKI ANALIZY ILOŚCIOWEJ}

Niniejszy artykuł został oparty na wynikach analizy zawartości o charakterze ilościowym i jakościowym, która jest niewielkim wycinkiem szerokich badań prowadzonych w ramach projektu naukowego realizowanego przez grupę badaczy z Uniwersytetu Śląskiego w Katowicach ${ }^{15}$. Analiza frekwencyjno-tematyczna zawartości pozwala na stwierdzenie częstotliwości występowania tematów lub aktorów, pewnych trendów w tym względzie w badanym okresie czasu. Dodatkowo positkowano się elementami analizy wartościująco-oceniającej, która polega na ocenie aktorów i tematów, poszukiwaniu związków między nimi a wartościami ${ }^{16}$. Entman wskazuje, że jednym z głównych zadań analizy zawartości jest ustalenie znaczenia tekstu, czyli identyfikacja i opis ramek ${ }^{17}$; w tym przypadku celem było poszukiwanie elementów ramy konfliktu.

Badanie objęło okres od 19 do 30 października 2015 r., kiedy opublikowano osiem wydań czterech tygodników opinii: „Polityka”, „Newsweek Polska”, „Wprost” i „Do Rzeczy". Zastosowano przygotowany na potrzeby grantu naukowego klucz kategoryzacyjny, zawierający 61 zmiennych. Analiza ramy konfliktu w okresie kampanii

14 W. Schulz, Komunikacja polityczna. Koncepcje teoretyczne i wyniki badań empirycznych na temat mediów masowych w polityce, przeł. J. Kożuch, Kraków 2006, s. 42, Media - Wydawnictwo Uniwersytetu Jagiellońskiego.

15 Politycy i dziennikarze. Powiązania między elitami sfery mediów i polityki w Polsce w perspektywie doświadczeń niemieckich, [online] http://www.politycyidziennikarze.us.edu.pl/, 24 VII 2018.

16 S. Michalczyk, Spoteczeństwo medialne. Studia z teorii komunikowania masowego, Katowice 2008, s. 292.

17 R.M. Entman, Framing: Toward Clarification of a Fractured Paradigm, "Journal of Communication” 1993, Vol. 43, nr 4, s. 57. 
parlamentarnej 2015 została oparta na 464 jednostkach, z których każda stanowiła wydzielony pod względem graficznym i tematycznym fragment, pochodzący z wybranych tygodników opinii. Analizując sposób opisu świata mediów masowych i polityki, trzeba mieć na uwadze linię redakcyjną poszczególnych tytułów, ponieważ w ramach prowadzonych badań założono, że właśnie sympatie redakcji mogą mieć wpływ na sposób przedstawiania mediów i polityki. „Newsweek Polska” to tygodnik o profilu lewicowo-liberalnym, „Polityka” liberalno-lewicowym, „Do Rzeczy” konserwatywno-liberalnym, a „Wprost” centroprawicowym, z liberalnym podejściem do kwestii gospodarczych.

Pilotażowe analizy zawartości czterech tygodników opinii były impulsem do głębszych analiz, których pokłosiem są prezentowane w tym artykule wyniki. Zaobserwowano, że wiele publikacji odnoszących się do bieżącej polityki ma wydźwięk negatywny. Ponadto w trakcie kampanii parlamentarnej 2015 mass media stały się istotnym tematem debaty politycznej, toczącej się między obozem rządzącym i opozycją; samo środowisko dziennikarskie również żywo debatowało nad kondycją polskich mediów masowych. W dyskursie na temat relacji media-polityka wyraźnie iskrzyło, a wzajemne oskarżenia redakcji o stronniczość stawały się istotnym wątkiem toczącej się kampanii ${ }^{18}$. Podstawowe pytanie badawcze brzmi: na jakich elementach i jak budowano ramę konfliktu, dokonując opisu świata polityki i mass mediów w okresie polskiej kampanii parlamentarnej $2015 \mathrm{w}$ badanych tygodnikach opinii?

Szczegółowe pytania badawcze stanowiące podstawę weryfikacji ramy konfliktu w analizowanych materiałach są następujące:

1. Jak w analizowanych materiałach oceniano świat polityki i mediów masowych?

2. Czy badane redakcje różnią się w opisie dziennikarstwa i polityki?

3. Czy w analizowanych materiałach ferowano konkretne zarzuty względem polityki i świata mediów masowych?

4. Czy w analizowanych tekstach można wskazać metaforykę wojenną charakterystyczną dla ramy konfliktu?

Główne hipotezy badawcze:

Hipoteza 1: Pomiędzy redakcjami badanych tygodników opinii występuje widoczna polaryzacja w ocenie świata mediów i polityki.

Hipoteza 2: Zarzut stronniczości stał się osią budowania ramy konfliktu w opisie funkcjonowania mediów masowych.

Hipoteza 3: Metaforyka wojenna jest elementem językowym budującym ramę konfliktu.

18 K. Brzoza, M. Kornacka-Grzonka, Narracja medialna wyrażona na oktadkach wybranych tygodników opiniipodczasparlamentarnejkampanii wyborczej2015r., [online] http://cejsh.icm.edu.pl/cejsh/ele ment/bwmeta1.element.desklight-722d8789-c30f-4a87-aa85-d9fb63a91fdb?q=bwmeta 1.ele ment.desklight-59ddb143-cde8-4d0d-a366-57fbca99a6b7;7\&qt=CHILDREN-STATELESS, 24 VII 2018. 
W analizowanym okresie dominowała tematyka związana z życiem politycznym: polityka była tematem aż 36,4\% opublikowanych materiałów. Ze względu na okres objęty badaniem największa grupa publikacji politycznych była związana z parlamentarną kampanią wyborczą (11,6\%). Tematyka polityczna najczęściej pojawiała się na łamach „Do Rzeczy”, następnie „Polityki”, „Wprost” i „Newsweek Polska”. Wśród wielu wyselekcjonowanych tematów występowały również media masowe (4,4\%). Najchętniej poruszali tę kwestię dziennikarze pracujący dla tygodnika „Do Rzeczy”, a najrzadziej związani z „Newsweek Polska”.

Politykę przede wszystkim krytykowano (zob. wykres 1) - ponad 31\% wypowiedzi na ten temat miało wydźwięk negatywny. Niemal równo rozkładał się udział wypowiedzi satyrycznych $(19,9 \%)$ i neutralnych $(20,6 \%)$. Trzeba również zwrócić uwagę na 2,1\% wypowiedzi nawołujących do protestu, czyli takich, których autorzy wyraźnie postulowali potrzebę przeciwstawienia się aktualnej sytuacji. Jeszcze mocniejszy wydźwięk miały wypowiedzi wzywające do działania, w których zachęcano do zerwania z biernością na rzecz podjęcia konkretnych działań, mających na celu wprowadzenie zmian w świecie polityki (5,7\%). Ramę konfliktu budowano głównie na wypowiedziach krytycznych i satyrycznych (łącznie $51,1 \%$ ). Stosowana przez redakcje satyra była żartobliwą formą wyrażania niechęci do świata polityki. Wniosek nasuwa się jeden: w okresie kampanii parlamentarnej 2015 politykę oceniono źle.

Wykres 1. Wypowiedzi na temat polityki (\%)

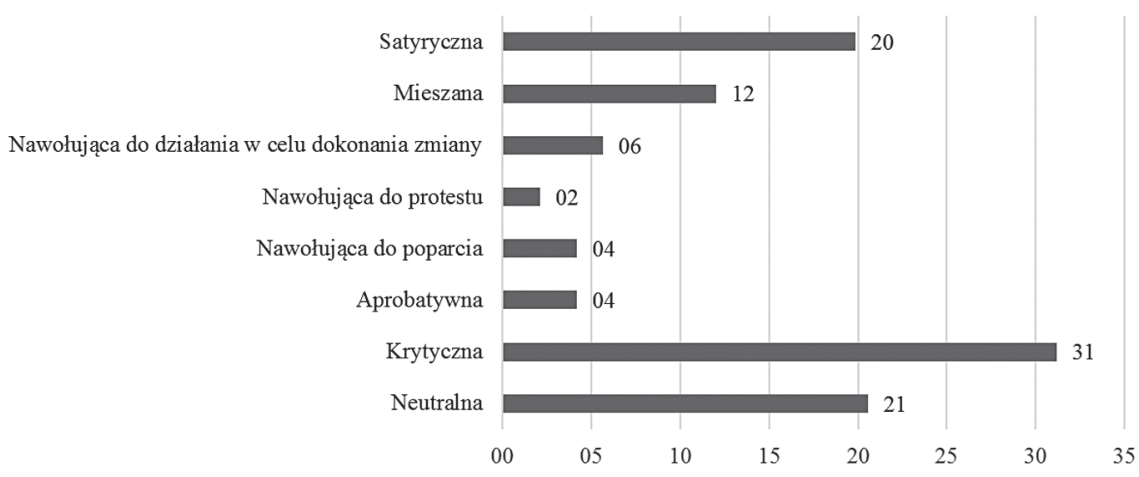

Źródło: badania własne.

W badanych materiałach swoje poglądy na temat polityki najchętniej wyrażali dziennikarze i miały one najczęściej wydźwięk neutralny, czyli nie pojawiała się w nich wyraźna ocena świata polityki $(8,5 \%)$. Natomiast krytycyzm można wskazać w wypowiedziach dziennikarzy $(8,5 \%)$ i ekspertów (8\%), czyli specjalistów w danej tematyce, bardzo często reprezentujących świat nauki (np. medioznawcy, politolodzy, socjolodzy, psycholodzy). Przedstawiciele biznesu nie krytykowali w ogóle. Co ciekawe, częściej krytyczny stosunek do bieżącej polityki wyrażali politycy ekipy rządzącej niż opozycji, która wydaje się w tym okresie nieco mniej kategoryczna i krytyczna w sądach. 
Aprobata $(1,4 \%)$ pojawiała się najczęściej w wypowiedziach innych osób, czyli wszystkich tych, którzy nie zostali zaklasyfikowani do pozostałych kategorii (np. przypadkowe osoby uczestniczące w jakimś wydarzeniu). Do poparcia wzywali politycy opozycji $(2,8 \%)$, do protestu dziennikarze $(1,4 \%)$, a do działania i zmian dziennikarze oraz politycy opozycji (po 2,1\%). Mieszane opinie na temat aktualnych wydarzeń politycznych wyrażali dziennikarze $(7,8 \%)$ i tzw. inne osoby $(1,4 \%)$. Podobnie po satyrę sięgali najczęściej dziennikarze (8,5\%), inne osoby $(5,7 \%)$ oraz liderzy opinii $(2,8 \%)$, czyli ludzie powszechnie szanowani, cieszący się autorytetem, choć niekoniecznie posiadający wiedzę ekspercką w temacie, którego dotyczyła dana wypowiedź (np. przedstawiciele świata kultury). W krytykowaniu polityki dominowała redakcja „Do Rzeczy”, która również najczęściej wzywała do zmiany. Po krytykę najrzadziej sięgali dziennikarze „Newsweek Polska”, natomiast redakcja „Polityki” najczęściej korzystała z satyry.

Przed wyborami obóz rządzący najczęściej krytykowała redakcja tygodnika „Do Rzeczy” (67\%), a najrzadziej „Polityki”, której dziennikarze najchętniej sięgali po satyrę (20\%) lub zachowywali neutralność (16\%). Aprobata wybrzmiewała bardzo rzadko, a najczęściej można było taki wydźwięk dostrzec na łamach „Newsweek Polska” (8\%). W odniesieniu do opozycji przed wyborami parlamentarnymi aprobatę wyrażała redakcja prawicowego tygodnika „Do Rzeczy” (22\%), krytykę dziennikarze „Newsweek Polska” (46\%), a satyra pojawiała się w publikacjach „Polityki” (24\%).

Po wyborach parlamentarnych, które doprowadzily do zmiany ekipy rządzącej i przejęcia władzy przez PiS, aprobata pojawiała się na łamach „Do Rzeczy” (7\%), krytyka była wyraźnie widoczna w materiałach publikowanych przez „Newsweek Polska” (33\%), zaś satyra najczęściej wybrzmiewała z tekstów zamieszczonych w „Polityce” (30\%). Co ciekawe, wydźwięk neutralny względem nowej ekipy rządzącej najczęściej można było dostrzec w materiałach „Do Rzeczy” (25\%). Nową opozycję po wyborach parlamentarnych krytykowały redakcje „Newsweek Polska” (44\%), „Do Rzeczy” (32\%) i „Wprost” (25\%). Dziennikarze „Do Rzeczy” (18\%) i „Wprost” (17\%) sięgali też po wydźwięk satyryczny względem opozycji. Aprobata pojawiała się bardzo rzadko (łącznie 9\% na łamach „Polityki” i „Wprost”). Przedstawione dane pokazują kolejny element powodujący napięcia w relacjach mediów masowych i polityki, czyli stronniczość redakcji, przejawiającą się bardzo mocno w zmianie wydźwięków z okresu przed wyborami parlamentarnymi i po nich. Można wnioskować, iż mamy do czynienia z przykładami partia bias, propagandas bias i ideological bias, które w swojej klasyfikacji odchyleń dotykających środowisko dziennikarskie wymienił John Street ${ }^{19}$.

Wypowiedzi na temat mediów pojawiały się w analizowanych tygodnikach rzadko, a ich autorami najczęściej byli dziennikarze. Opinie na temat mass mediów (zob. wykres 2) miały wydźwięk neutralny (28\%) lub aprobatywny (20\%). Trzeba zwrócić uwagę na wypowiedzi nawołujące do działania w celu dokonania zmiany (8\%), w których pojawiał się głównie postulat odpolitycznienia mediów masowych, oraz na wypowiedzi wzywające do protestu, wyrażające potrzebę sygnalizowania dezaprobaty wobec aktualnej sytuacji na rynku mediów masowych (8\%). Satyra widoczna w badanych

19 Zob. S. Michalczyk, Spoteczeństwo medialne..., s. 269-270. 
tygodnikach to także forma wyrażania niezadowolenia i wytykania błędów (16\%). Suma wypowiedzi krytycznych, satyrycznych, nawołujących do działania w celu dokonania zmiany oraz do protestu wynosi $40 \%$, a tym samym wydźwięk opublikowanych wypowiedzi na temat mediów masowych jest raczej krytyczno-satyryczny.

Dziennikarze najczęściej prezentowali opinie neutralne i satyryczne co do mass mediów (po 16\%). Eksperci oceniali je neutralnie lub pozytywnie. Po krytykę sięgali politycy opozycji i dziennikarze (po 4\%). Do dokonania zmiany w mediach masowych wzywali dziennikarze i inne osoby (po 4\%). Patrząc przez pryzmat poszczególnych tygodników, można stwierdzić, że najwięcej krytyki względem mass mediów można odnaleźć na łamach „Do Rzeczy”. Redakcja „Wprost” najczęściej zachowywała neutralność w wypowiedziach na ten temat, a dziennikarze „Polityki” wykorzystywali wydźwięk satyryczny.

Wykres 2. Wypowiedzi na temat mass mediów (\%)

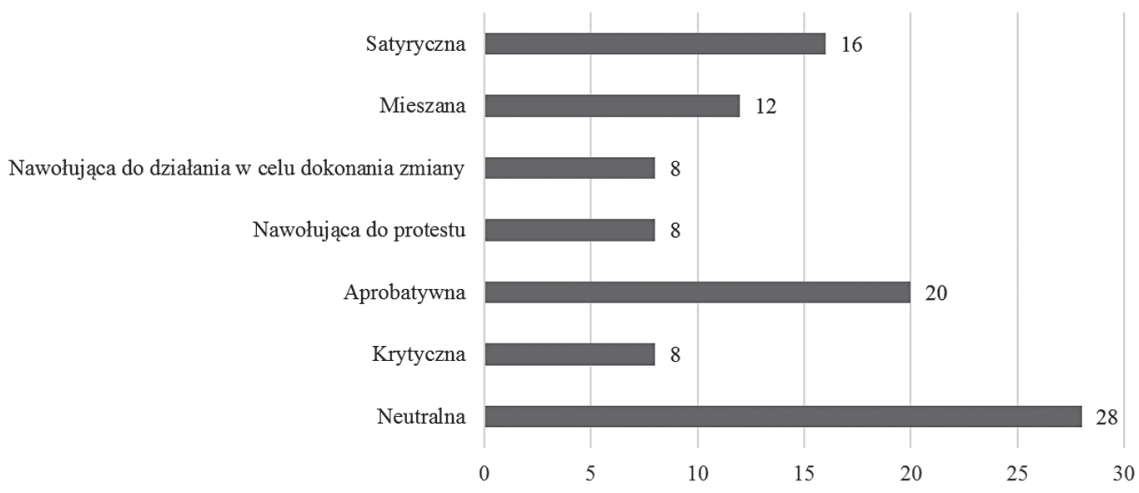

Źródło: badania własne.

W materiałach opublikowanych na łamach badanych tygodników sprawdzono, kto i jak ocenia wzajemne oddziaływanie świata mass mediów i polityki ${ }^{20}$. Dziennikarze $(59,5 \%)$, liderzy opinii $(13,5 \%)$ oraz politycy opozycji i inne osoby $(10,8 \%)$ to podmioty, które najchętniej wyrażały swoje poglądy na ten temat. $\mathrm{Z}$ przeprowadzonych analiz wynika, że najczęściej pojawiała się opinia, iż media mają wpływ na politykę $(21,6 \%)$, co byłoby zgodne z paradygmatem udziału we władzy, zgodnie z którym mass media pełnią rolę czwartej władzy. Nieco mniej wskazań uzyskały zdania: media krytykują tylko opozycję (18,9\%), media dopuszczają do głosu tylko jedną stronę (13,5\%), media sprzyjają ekipie rządzącej $(10,8 \%)$. Najrzadziej występowały tezy, że media nie wpływają na politykę, a w mass mediach istnieje pluralizm $(5,4 \%)$ oraz że media wzajemnie

20 K. Brzoza, D. Głuszek-Szafraniec, P. Szostok, Upolitycznienie przekazu prasowego w wybranych polskich tygodnikach opinii. Wstępny raport z badań, [online] http://www.journals.us.edu.pl/index.php/ PP/article/view/6107/4375, 25 VII 2018; K. Brzoza, D. Głuszek-Szafraniec, P. Szostok, „Wieszczenie finis poloniae", czyli jak relacjonowano wybory parlamentarne... 2015 w polskich tygodnikach opinii, [w:] Jezyk a media. Wzory komunikacji we wspótczesnych mediach, red. B. Skowronek, E. Horyń, A. Walecka-Rynduch, Kraków 2018, s. 99-115. 
się zwalczają (5,4\%). Dziennikarze wskazywali, że media mają wpływ na politykę oraz krytykują tylko opozycję (po 10,8\%), natomiast bardzo rzadko wysuwali twierdzenie, że media wpływają na opinię publiczną $(2,7 \%)$. W badanych materiałach ekspert sugerował, że media dopuszczają do głosu tylko jedną stronę (2,7\%). Przeprowadzona analiza zawartości wykazała, że w opinii polityka ekipy rządzącej media wpływają na opinię publiczną (2,7\%), zaś polityk opozycji twierdził, że dopuszczają do głosu jedną stronę, krytykują tylko opozycję i sprzyjają ekipie rządzącej. Lider opinii podobnie dostrzegał stronniczość w działaniach dziennikarzy, ale jednocześnie wyraził pogląd, że mass media wpływają na politykę i opinię publiczną oraz manipulują agendą. Redakcje „Newsweek Polska” i „Do Rzeczy” stwierdzają, że media dopuszczają do głosu tylko jedną stronę. Na łamach „Polityki” najczęściej pojawiał się pogląd, iż media sprzyjają opozycji. Natomiast w materiałach „Do Rzeczy” i „Polityki” można było odnaleźć stwierdzenie, że media masowe sprzyjają ekipie rządzącej.

Tabela 1. Wpływ mass mediów na politykę w wypowiedziach z badanych materiałów (\%)

\begin{tabular}{|c|c|c|c|c|c|c|c|}
\hline \multirow[b]{2}{*}{$\begin{array}{l}\text { Rodzaj wypowiedzi na temat wpływu } \\
\text { mass mediów na politykę }\end{array}$} & \multicolumn{6}{|c|}{ Osoba wypowiadająca się w materiale } & \multirow[b]{2}{*}{ 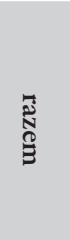 } \\
\hline & 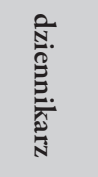 & 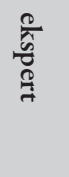 & 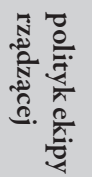 & 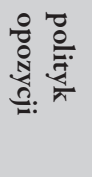 & 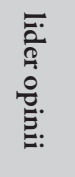 & $\begin{array}{l}\text { E. } \\
\frac{D}{2} \\
0 \\
0 \\
\frac{0}{0}\end{array}$ & \\
\hline Brak wpływu/pluralizm mediów & 5,4 & - & - & - & - & - & 5,4 \\
\hline Dopuszczanie do głosu tylko jednej strony & 5,4 & 2,7 & - & 2,7 & 2,7 & - & 13,5 \\
\hline Wpływ na opinię publiczną & $2,7 \%$ & - & 2,7 & - & 2,7 & - & 8,1 \\
\hline Manipulowanie agendą & $5,4 \%$ & - & - & - & 2,7 & - & 8,1 \\
\hline Wpływ na politykę & $10,8 \%$ & - & - & 2,7 & 2,7 & 5,4 & 21,6 \\
\hline Sprzyjanie ekipie rządzącej & $5,4 \%$ & - & - & 2,7 & 2,7 & - & 10,8 \\
\hline Sprzyjanie opozycji & $8,2 \%$ & - & - & - & - & - & 8,2 \\
\hline Wzajemne zwalczanie się & 5,4 & - & - & - & - & - & 5,4 \\
\hline Krytykowanie tylko opozycji & 10,8 & - & - & 2,7 & - & 5,4 & 18,9 \\
\hline Razem & 59,5 & 2,7 & 2,7 & 10,8 & 13,5 & 10,8 & \\
\hline
\end{tabular}

Źródło: badania własne.

Ekipa rządząca wpływa na media - to pogląd najczęściej wyrażany na łamach badanych tygodników (50\%) przez dziennikarzy, polityków opozycji oraz inne osoby (po 15\%). Sami politycy ekipy rządzącej zdawali się nie dostrzegać, iż wpływają na mass media. Najrzadziej pojawiały się opinie o niezależności mass mediów i oddziaływaniu na nie Kościoła czy świata biznesu, a także twierdzenie, że politycy manipulują mediami (po 5\%). Dziennikarze na łamach badanych tygodników opinii najczęściej twierdzili, że na media masowe wpływa ekipa rządząca (15\%) oraz opozycja (10\%). Ekspert 
wyrażał pogląd, że politycy robią wszystko żeby znaleźć się w mediach (5\%), ale dostrzegał wpływ ekipy rządzącej na media (5\%). Polityk ekipy rządzącej stwierdził, że politycy manipulują mediami (5\%), a polityk opozycji zauważył oddziaływanie ekipy rządzącej na świat mass mediów (15\%).

Tabela 2. Wpływ polityki na mass media w wypowiedziach z badanych materiałów (\%)

\begin{tabular}{|c|c|c|c|c|c|c|}
\hline \multirow[b]{2}{*}{$\begin{array}{l}\text { Rodzaj wypowiedzi na temat wpływu } \\
\text { polityki na mass media }\end{array}$} & \multicolumn{5}{|c|}{ Osoba wypowiadająca się w materiale } & \multirow[b]{2}{*}{ 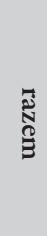 } \\
\hline & 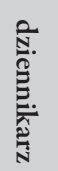 & 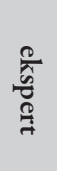 & 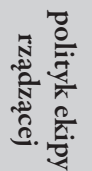 & 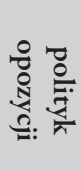 & 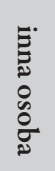 & \\
\hline Ekipa rządząca wpływa na media & 15 & 5 & - & 15 & 15 & 50 \\
\hline Opozycja wpływa na media & 10 & - & - & - & - & 10 \\
\hline Media są niezależne & 5 & - & - & - & - & 5 \\
\hline Kościół wpływa na media & 5 & - & - & - & - & 5 \\
\hline Biznes wpływa na media & 5 & - & - & - & - & 5 \\
\hline $\begin{array}{l}\text { Politycy robią wszystko, aby znaleźć się } \\
\text { w mediach }\end{array}$ & 5 & 5 & - & - & - & 10 \\
\hline Politycy manipulują mediami & - & - & 5 & - & - & 5 \\
\hline Inna wypowiedź & 10 & - & - & - & - & 10 \\
\hline Razem & 55 & 10 & 5 & 15 & 15 & \\
\hline
\end{tabular}

Źródło: badania własne.

Na łamach „Polityki” najczęściej pojawiało się stwierdzenie, że opozycja wpływa na media masowe. Redakcja prawicowego tygodnika „Do Rzeczy” wyrażała odwrotne przekonanie: że to ekipa rządząca wywiera na nie wpływ. Pozostałe dwie redakcje raczej unikają jednoznacznych ocen.

\section{RAMA KONFLIKTU. REZULTATY ANALIZY JAKOŚCIOWEJ}

W badanym okresie w publikacjach czterech wybranych tygodników opinii można wskazać kilka pól antagonizmów występujących między reprezentantami mediów a polityki:

1. Ocena dziennikarstwa i polityki.

2. Wieszczenie zmian personalnych $w$ mediach publicznych po wyborach parlamentarnych.

3. Wyborcza wygrana PiS oznaczająca przejęcie pełnej kontroli tej partii nad mediami publicznymi. 
4. Wzajemne oskarżenia redakcji o stronniczość i sympatyzowanie z konkretnym ugrupowaniem politycznym.

5. Zapowiedź kontroli poczynań nowego rządu, czyli pełnej realizacji funkcji watchdoga przez dziennikarzy.

6. Metafory wojny w nagłówkach badanych publikacji.

7. Okładki jako wizualizacja ramy konfliktu.

\section{Ocena dziennikarstwa i polityki}

Na łamach tygodnika „Do Rzeczy” Piotr Gursztyn sygnalizuje: Wolne media sqa częścia demokracji, ale mają nie tylko prawa, lecz także obowiazki wynikajace z ich uprzywilejowanej roli, dlatego redakcja podkreśla, że dziennikarze powinni się opowiadać po stronie ofiar przeciwko tym, którzy łamią prawo ${ }^{21}$. W badanych publikacjach przypisuje się mass mediom określone zadania, takie jak rozliczenie elit politycznych. Wrzawa kampanii wyborczej mocno zaktócata rzeczywisty obraz państwa, jaki kolejnej ekipie zostawia rzad Ewy Kopacz. [...] Dziś postanowiliśmy się skupić na zaniechaniach i zagrożeniach, jakie czyhaja na kolejna administracje. Problemach, z jakimi przyjdzie jej się zmierzyć już $w$ najbliższych tygodniach ${ }^{22}$. Redakcja prawicowego tygodnika „Do Rzeczy” idzie dalej i wprost pisze o potrzebie zmiany rządzących: Dlaczego pozwalamy się okradać? Dlaczego od tylu lat utrzymujemy u wtadzy ludzi, którzy pozwalaja nas okradać [...]? Dlaczego nie zastapimy ich tymi, którzy będą dbali o stan kasy Polski ${ }^{23}$ Media masowe mają również moc sprawczą w zakresie kreacji liderów i tworzenia wielkich, medialnych osobowości. Na łamach „Polityki” odniesiono się do debaty telewizyjnej z udziałem Adriana Zandberga w takich słowach: Oto okazuje się, że jeden występ, potem dodatkowe dwa, trzy w telewizyjnym studiu wystarcza do "objawienia się" lidera ${ }^{24}$. Media obrazują kandydata w wyborach poprzez różne triki, bo [...] kulisy spotkań z wyborcami wygladaja zupetnie inaczej niż to, co pojawia się na ekranach ${ }^{25}$.

Autorzy badanych publikacji oceniają stan polskiego dziennikarstwa oraz świata polityki negatywnie: polskie dziennikarstwo jest stabloidyzowane, także w zakresie relacjonowania twardych politycznych wydarzeń. Dziennikarze dziś traktuja programy wyborcze jako zbędny dodatek, który nie podgrzewa emocji, nie generuje klików i sensacji. Zatracenie misji przez media nie pozwala nam prawidtowo oceniać polityków i ich pracy grzmi Sebastian Kaleta na łamach „Wprost" ${ }^{26}$. Zaprasza się dwóch polityków w nadziei, że skocza sobie do gardta. To podnosi ogladalność. [...] Politycy się do tego stylu szybko dostosowali. Wielu z nich, jak zobaczy kamerę, zachowuje sie jak mój pies, kiedy zobaczy

\footnotetext{
21 P. Gursztyn, Zapomniana „dePiSyzacja”, „Do Rzeczy” 2015, nr 44, s. 37.

22 P. Rożyński [i in.], Nowy rząd zastanie pole minowe, „Wprost” 2015, nr 44, s. 28.

23 P. Gabryel, Dlaczego pozwalamy się okradać?, „Do Rzeczy” 2015, nr 43, s. 86.

24 J. Paradowska, Przyszta zmiana ale jaka, „Polityka” 2015, nr 44, s. 14.

25 E. Olczyk, J. Miziołek, Walka o gtosy ulicy, „Wprost” 2015, nr 43, s. 22.

26 S. Kaleta, Debata, której nie ma, „Wprost” 2015, nr 43, s. 23.
} 
drzewo. Musza skorzystac ${ }^{27}$. Przytoczone słowa wypowiedział polityk PSL Stanisław Żelichowski, który wyraził w ten sposób pogląd na temat relacji mass mediów i polityki. Reżyser Marian Marzyński w wywiadzie udzielonym redakcji „Newsweek Polska” stwierdzit: Zamiast analizować programy, dziennikarze zastanawiaja się, czy kamera, która prowadzita Szydto, wygrata z kamera, która prowadzita Kopacz. [...] to jest poziom wczesnego przedszkola. Polska za pomoca telewizji upada umystowo ${ }^{28}$.

Mimo mało pochlebnych ocen polskiego dziennikarstwa, jego poziom i tak jest [...] wyższy niż poziom polityki. Zwtaszcza tej mainstreamowej [...] rozmawiając nawet z politykami z samej góry, mam czessto wrażenie, że zderzam się z mentalnościa magistrackich urzędników, którzy walczq o lepsza posadę i większe mieszkanie. I to siępotem przektada na poziom ich pomystów politycznych ${ }^{29}$. Większość ewidentnych stabości naszego pansstwa ma źródto w polityce [...], która za naszym przyzwoleniem tatwo odrywa się od rzeczywistości, przestaje być odpowiedzialna, racjonalna, staje się medialnym reality show, gdzie w końcu mamy zagtosować na zwycięzcę widowiska $a^{30}$ - ocenia Jerzy Baczyński. Media i politycy szukajacy prawdy nie takiej, jaka jest, ale takiej, jaka być powinna, kreują podwójna rzeczywistos $c^{31}$. Wniosek Marzeny Hausman nie napawa optymizmem i w zasadzie jest jednoznacznym stwierdzeniem, że media i politycy manipulują opinią publiczną.

Drugą osią budującą ramy konfliktu w badanych publikacjach tygodników opinii było przewidywanie zmian personalnych w mediach publicznych. Z jednej strony prawicowa redakcja „Do Rzeczy” podkreślała konieczność nowej obsady stanowisk w mediach publicznych, a z drugiej dziennikarze „Newsweek Polska” traktowali zapowiadaną reorganizację jako element politycznej rozgrywki i drogę do upolitycznienia publicznych redakcji. Media publiczne - pozostawiono w stanie prawnym i finansowym, w jakim znalazty się po upadku IV RP - i w tej formie doczekaja być może triumfalnego jej powrotu 32 - czytamy na łamach „Polityki”. Roman Giertych w wywiadzie dla „Newsweek Polska" jednoznacznie stwierdził, że jednym z celów Jarosława Kaczyńskiego jest przejęcie kontroli nad mediami publicznymi: Media publiczne podporzadkuje szybko, z prywatnymi będzie się starat dogadać, straszą, że zrobi z nimi porządek ekonomiczny. To najprostsza, ale i najskuteczniejsza metoda ${ }^{33}$. Z przytoczonej wypowiedzi jasno wynika, że przedmiotem konfliktu między PO i PiS uczyniono media publiczne, a ściślej możliwość sprawowania nad nimi kontroli politycznej. Wraz z obsada rzadu planowana jest też czystka w mediach publicznych [...]. PiS musi zmienić sktad Krajowej Rady Radiofonii i Telewizji. [...] To otworzy drogę do przejęcia TVP i Polskiego Radia ${ }^{34}$. Lider PiS po wygranych wyborach obiecat udziat w medialnym torcie kazdej $z$ prawicowych

Polityka i obyczaje, „Polityka” 2015, nr 43, s. 114.

28

29

P. Bratkowski, Chopin wygrywa wybory, „Newsweek Polska” 2015, nr 44, s. 38.

Tamże, s. 38.

J. Baczyński, Prognoza ostrzegawcza, „Polityka” 2015, nr 43, s. 16.

M. Hausman, Przedsionek folwarku zwierzęcego, „Wprost” 2015, nr 43, s. 63.

J. Baczyński, Prognoza ostrzegawcza..., s. 18.

A. Pawlicka, Rewolucja autorytarna, „Newsweek Polska” 2015, nr 44, s. 22.

A. Pawlicka, M. Krzymowski, Ekipa prezesa, „Newsweek Polska” 2015, nr 43, s. 18. 
redakcji [...] na pewno dostana czas antenowy na programy, ale wtadze nad mediami musza sprawować ludzie pewni, bliżej związani z partią ${ }^{35}$. Podobny wydźwięk ma komentarz Janiny Paradowskiej zamieszczony na stronach „Polityki”: bieg tzw. niepokornych po wtadze w mediach publicznych przybrat juz charakter sprintu na ostatniej prostej ${ }^{36}$. Natomiast dziennikarze „Do Rzeczy” czekają na zmiany personalne w redakcjach. W opinii dziennikarzy prawicowego tygodnika aktualnie mass media są stronnicze, a każde ktamstwo na temat PiS jest rozbrajane w btyskawicznym tempie. Jednocześnie spadta rola wielkich gazet $[. .$.$] i wielkich stacji telewizyjnych { }^{37}$.

Wzajemne oskarżenie się o stronniczość przedstawicieli redakcji opowiadających się za różnymi obozami politycznymi to kolejny zauważalny element budujący ramę konfliktu. Z publikacji tygodnika „Do Rzeczy” wyłaniał się pogląd, iż zmiany w mediach są potrzebne, ponieważ media są tendencyjne i wyraźnie sprzyjają ekipie rządzącej.

Centralnym elementem dyskusji na temat mediów w okresie kampanii parlamentarnej 2015 była telewizja publiczna, oskarżana przez PiS i dziennikarzy prawicowych redakcji o sprzyjanie ekipie rządzącej. Kierownictwo telewizji publicznej zapiera się stronniczości uderzającej w prezydenta. Tymczasem daje kolejne jej dowody [...]. Tu również nie ja jeden, ale wielu komentatorów i internautów odniosto nieodparte wrażenie, $\dot{z}$ e obecny prezydent traktowany jest zupetnie inaczej, niż byt przy podobnych okazjach traktowany przez TVP poprzedni. [...] I bez brnięcia w szczegóty nie można przecież nie zauważyć pasji, z jaka pracownicy mediów publicznych atakuja przy każdej okazji opozycje w stylu podobnym do umundurowanych ,dziennikarzy" TVP z lat 80. [...] to jeszcze jeden dowód na to, że w obecnej, peeselowsko-platformerskiej TVP unosi się ten sam zapach co za czasów PRL i wywietrzenie go jest jednym z gtównych warunków uzdrowienia polskiej debaty publicznej ${ }^{38}$. Na łamach prawicowego tygodnika pojawia się ciekawa opinia na temat czasopisma „Press”: To z tego wtaśnie pisma osiem lat temu się dowiedziatem, że po zlikwidowaniu zagrożenia dla demokracji, jakim byt PiS, zadaniem dziennikarstwa jest nie dopuścić do tego, aby kiedykolwiek wrócit on do wtadzy ${ }^{39}$. Przywołany cytat to bardzo wyraźna sugestia uwikłania mediów w życie polityczne.

Na łamach „Polityki” można było przeczytać, że dziennikarzy niepokornych mediów od dawna rączki [...] świerzbią, a pośladki tęsknią do stotków choćby $w T V P^{40}$. Prawicowe mass media traktowane są jak medialne zaplecze partii Jarosława Kaczyńskiego, tę bezwzględność lider PiS zaszczepit nie tylko swojemu ugrupowaniu, ale też medialnej drużynie „niepokornych." [...] Obrona politycznej wspólnoty uzasadnia akty nawet największego grubiaństwa ${ }^{41}$.

Redakcje badanych tygodników nie ukrywały swoich sympatii politycznych, o czym dobitnie świadczy m.in. taki fragment: [...] trzeba jednak dużo cierpliwości i pogodzenia

\footnotetext{
Tamże, s. 18.

36 J. Paradowska, Powotania - odwotania, „Polityka” 2015, nr 43, s. 11.

37 P. Siemka, PiS i mission impossible, „Do Rzeczy” 2015, nr 43, s. 24.

38 R.A. Ziemkiewicz, TVP do wietrzenia, „Do Rzeczy” 2015, nr 44, s. 58-59.

39 Tenże, Poemat dla naiwnych, „Do Rzeczy” 2015, nr 43, s. 14.

40 S. Tym, Pakiecik, „Polityka” 2015, nr 44, s. 105.

${ }_{41}$ M. Janicki, W. Władyka, Kaczyński: tak - nie, „Polityka” 2015, nr 43, s. 13-15.
} 
sie z utrata stanowisk i wtadzy, a na to Platforma nie jest gotowa. Stad jej rozpaczliwe ruchy i nadzieja, że koalicja „wszyscy przeciwko PiS” pomoże utrzymać się jej jeszcze jakiś czas przy wtadzy ${ }^{42}$ - pisała redakcja „Do Rzeczy”. Natomiast na łamach „Polityki” po wygranej PiS w wyborach parlamentarnych Jerzy Baczyński wprost wyraził antypatię do lidera wygrywającej partii: Jarostaw Kaczyński, gtówny autor tego sukcesu, staje się faktycznym Naczelnikiem Panstwa [...]. Gratulujemy, ale się nie cieszymy ${ }^{43}$. Redaktor naczelny „Newsweek Polska” otwarcie napisał, że dla dziennikarzy niepokornych bycie beneficjentem obiecywanej przez Kaczyńskiego „redystrybucji prestizu” to prostacka pazerność na stanowiska zajmowane przez innych ${ }^{44}$, bo Poset PiS: - Jarostaw obiecat udziat $w$ medialnym torcie każdej z prawicowych redakcji ${ }^{45}$. Dziennikarze „Do Rzeczy” zapowiadali, że ostatnie dni kampanii wyborczej będą czasem, kiedy Platforma i sprzyjające jej media [...] z pewnościa spróbują rozhuśtać emocje antypisowskie ${ }^{46}$.

Kolejnym elementem budującym ramę konfliktu w publikacjach tygodników opinii poddanych analizie zawartości jest zapowiedź realizacji przez media funkcji kontrolnej względem świata polityki. Redakcja „Polityki” stawia się w roli watchdoga w słowach: Tak czy owak ida ciekawe czasy. Dla gazety to zawsze dobrze. Chcielibyśmy szczerze, żeby wszystkie nasze obawy zwiazane $z$ nowa wtadza okazaty się wyolbrzymione, zgota bezpodstawne. Jako ludzie matej wiary, nad czym pewnie trzeba ubolewać, będziemy się jednak przygladać, czepiać, krytykować, ostrzegać, jak będzie za co pochwalimy. Nie odkreślamy przesztości PiS ani PO gruba kreska, nie popadamy w amnezje ${ }^{47}$.

Rama konfliktu była także widoczna w nagłówkach, w których pojawiały się metafory wojny, walki, nadchodzącej zmiany: Armia na topatkach ${ }^{48}$, Platforma pozamiata$n a^{49}$, Na celowniku Andrzej Duda ${ }^{50}$, TVP do wietrzenia ${ }^{51}$, Demokracja na podstuch $u^{52}$, Rewolucja przy urnach ${ }^{53}$, Rewolucja autorytarna ${ }^{54}$, Walka o gtosy na ulicy ${ }^{55}$, Taka piękna katastrofa ${ }^{56}$, Gwóźdź do trumny SLD $D^{57}$.

\footnotetext{
K. Baranowska, Pompowanie Petru, „Do Rzeczy” 2015, nr 43, s. 29.

J. Baczyński, Nadzieja bez wiary, „Polityka” 2015, nr 44, s. 11.

4 T. Lis, Czyja będzie Polska, „Newsweek Polska” 2015, nr 43, s. 2.

45 A. Pawlicka, M. Krzymowski, Ekipa Prezesa..., s. 18.

46 P. Semka, PiS i mission impossible..., s. 24.

47 J. Baczyński, Nadzieja bez wiary..., s. 11.

48 A. Bilski, Armia na topatkach, „Do Rzeczy” 2015, nr 43, s. 30.

S. Cenckiewicz, Platforma pozamiatana, „Do Rzeczy” 2015, nr 43, s. 58.

S. Kmiecik, Na celowniku Andrzej Duda, „Do Rzeczy” 2015, nr 44, s. 60.

$51 \quad$ R.A. Ziemkiewicz, TVP do wietrzenia..., s. 58.

52 C. Michalski, P. Chatkowski, Demokracja na podstuchu, „Newsweek Polska” 2015, nr 43, s. 26.

53 T. Lis, Rewolucja przy urnach, „Newsweek Polska” 2015, nr 44, s. 2.

54 A. Pawlicka, Rewolucja autorytarna..., s. 22.

55 E. Olczyk, J. Mizołek, Walka o gtosy na ulicy..., s. 22.

56 E. Olczyk, Taka piękna katastrofa, „Wprost” 2015, nr 44, s. 22.

57 K. Mroziński, Gwóźdź do trumny SLD, „Wprost” 2015, nr 44, s. 36.
} 
Rysunek 1. Okładki analizowanych tygodników jako przykład wizualizacji ramy konfliktu

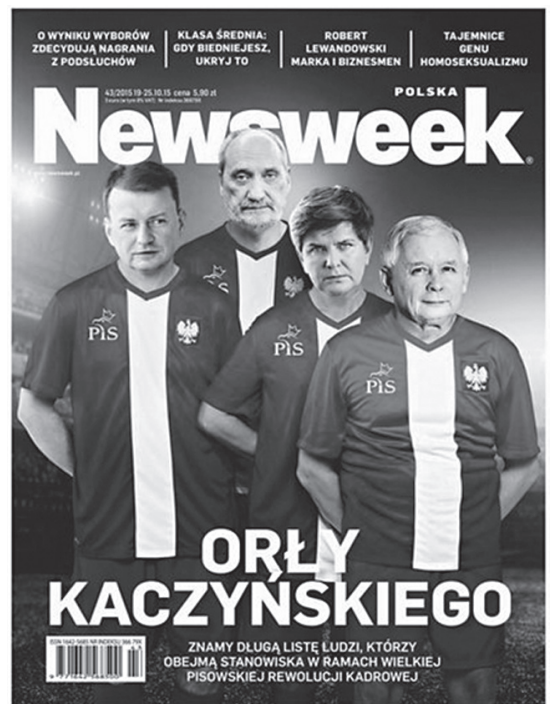

„Newsweek Polska” 2015, nr 43

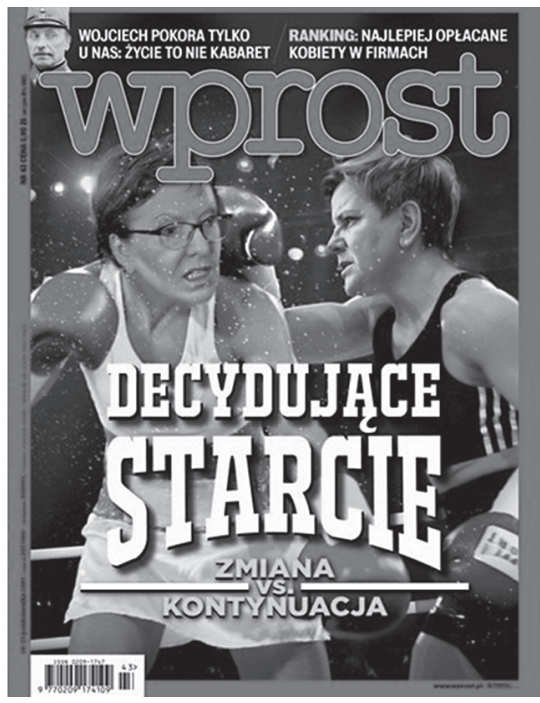

„Wprost” 2015, nr 43

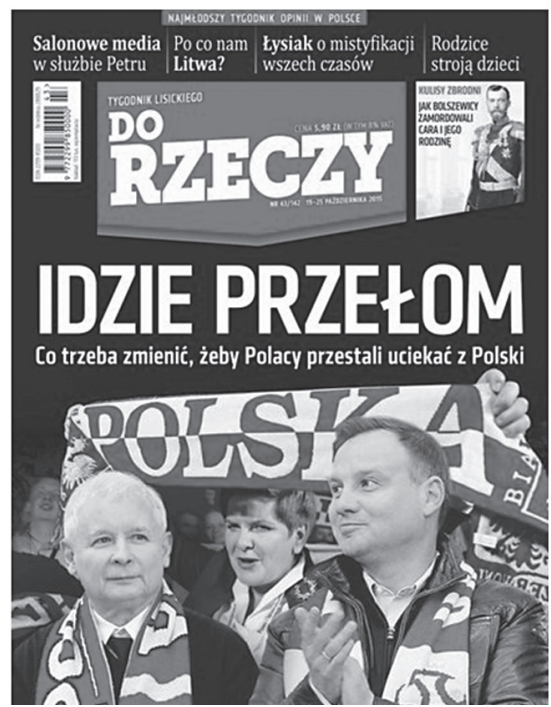

„Do Rzeczy” 2015, nr 43

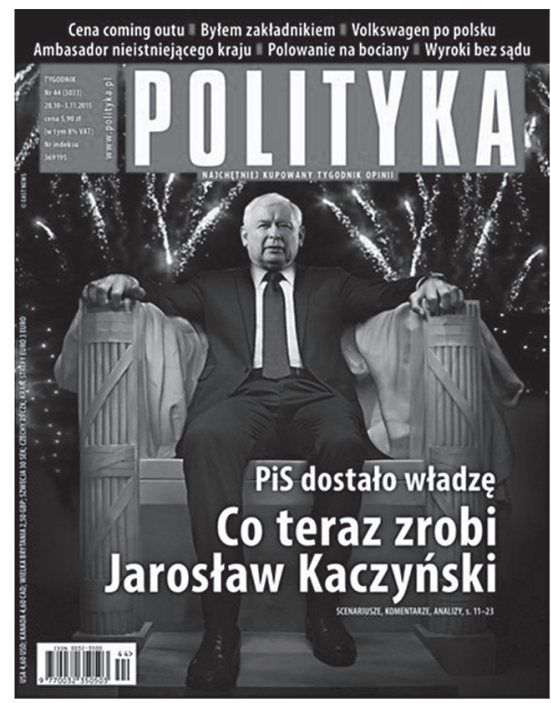

„Polityka” 2015, nr 44

W przypadku tygodników bardzo ważnym elementem jest okładka, która sygnalizuje, jaki temat redakcja uznała w danym okresie za najważniejszy. Ponadto może przyciągnąć uwagę potencjalnego czytelnika i skłonić do zakupu czasopisma. Okładki w okresie kampanii parlamentarnej 2015 wyrażały sympatie i antypatie polityczne redakcji oraz były wizualnym odbiciem ramy konfliktu, którą budowali dziennikarze badanych 
tytułów. Na okładkach prawicowego tygodnika „Do Rzeczy” widać sympatię do Jarosława Kaczyńskiego, który jest niezniszczalny ${ }^{58}$, i radość redakcji w przypadku przejęcia władzy przez PiS, bo to oznacza, że idzie przetom ${ }^{59}$. Redakcja „Newsweek Polska” obawia się wygranej PiS, która jest zapowiedzią nadejścia Ortów Kaczyńskiego, wielkiej pisowskiej rewolucji kadrowej ${ }^{60}$ oraz wtadzy niemal absolutnej Jarostawa Kaczyńskiego6 ${ }^{61}$.

Badane okładki tygodnika „Wprost” ukazywały wybory parlamentarne jako decydujace starcie dwóch najważniejszych ugrupowań politycznych i wybór zmiana vs. kontynuacja ${ }^{62}$. Na okładce numeru 43 „Wprost” ramę konfliktu pokazano wyraźnie i otwarcie, prezentując Beatę Szydło i Ewę Kopacz walczące na ringu bokserskim. Negatywne emocje wywołuje również okładka 44 numeru tego pisma, na której Jarosława Kaczyńskiego ukazano tak, jak głównego bohatera serialu House of Cards - Francisa Underwooda, wyznawcę stwierdzenia „cel uświęca środki”.

\section{ZAKOŃCZENIE}

Przeprowadzone analizy pozwoliły na weryfikację postawionych hipotez badawczych:

- Hipoteza 1: Pomiędzy redakcjami badanych tygodników opinii występuje widoczna polaryzacja w ocenie świata mediów i polityki.

Politykę najczęściej krytykowano, natomiast o mass mediach wyrażano opinie neutralne, choć wypowiedzi krytycznych, nawołujących do zmiany i protestu, również nie brakowało. Badania wykazały, że ilościowo wypowiedzi krytyczne wobec mediów masowych dominowały na łamach tygodnika „Do Rzeczy”. Redakcja prawicowego tytułu oskarżała media publiczne o sprzyjanie ekipie rządzącej. Po krytykę sięgat także „Newsweek Polska”, ale atak kierował na media prawicowe, które po wyborach wygranych przez PiS, w nagrodę za lojalność wobec ugrupowania Jarosława Kaczyńskiego, opanują media publiczne. Dziennikarze „Wprost” unikali jednoznacznych ocen, dlatego wykorzystywali wypowiedzi neutralne, a „Polityka” posiłkowała się satyrą. Polityka oceniana była znacznie gorzej niż mass media, a najwięcej krytyki widać było na łamach „Do Rzeczy”, zwłaszcza wobec koalicji rządzącej. Redakcja Tomasza Lisa również chętnie sięgała po krytykę, ale uderzała w opozycję. W „Polityce” widać było głównie krytykę i satyrę w zakresie oceny polskiego życia politycznego, a najbardziej neutralna w swoich ocenach pozostawała redakcja „Wprost”.

- Hipoteza 2: Zarzut stronniczości stał się osią budowania ramy konfliktu w opisie funkcjonowania mediów masowych.

$\mathrm{Na}$ łamach badanych tygodników dominowały poglądy sytuujące media w roli czwartej władzy oddziałującej na świat polityki. Jednocześnie opinie na temat

\footnotetext{
58 Okładka „Do Rzeczy” 2015, nr 44.

59 Okładka „Do Rzeczy” 2015, nr 43.

60 Okładka „Newsweek Polska” 2015, nr 43.

61 Okładka „Newsweek Polska” 2015, nr 44.

62 Okładka „Wprost” 2015, nr 43.
} 
oddziaływania mass mediów na politykę pokazały, że niewielki odsetek wypowiedzi zawierał przekonanie o niezależności mediów masowych. Co istotne, redakcje zdawały się nie dostrzegać własnej stronniczości, przy jednoczesnym eksponowaniu i oskarżaniu redakcji innych badanych tytułów o sympatyzowanie z określoną opcją polityczną. Redakcje „Newsweek Polska” i „Do Rzeczy” stwierdzały, że media dopuszczają do głosu tylko jedną stronę i właśnie w tych dwóch tytułach najwyraźniejsza była zmiana sposobu oceniania świata polityki w okresie przed wyborami parlamentarnymi i po nich.

- Hipoteza 3: Metaforyka wojenna jest elementem językowym budującym ramę konfliktu.

Metafory wojny charakterystyczne dla wyrażania konfrontacji pojawiały się w wielu badanych nagłówkach. Antagonizmy między światem mediów masowych a polityki osadzono na: a) ocenie dziennikarstwa i polityki, której dokonały redakcje tygodników, b) zapowiedziach zmian personalnych w mediach publicznych, c) straszeniu rządami PiS, które będą się opierać na kontroli mediów publicznych, d) wzajemnych oskarżeniach dziennikarzy o stronniczość, e) deklaracjach kontroli poczynań nowego rządu.

\section{BIBLIOGRAFIA}

Brzoza K., Głuszek-Szafraniec D., Szostok P., Upolitycznienie przekazu prasowego w wybranych polskich tygodnikach opinii. Wstępny raport z badań, „Political Preferences” 2017, nr 16, [online] http://www.journals.us.edu.pl/index.php/PP/article/view/6107/4375, https://doi. org $/ 10.6084 / \mathrm{m} 9$.figshare. 5605678 .

Brzoza K., Głuszek-Szafraniec D., Szostok P., „Wieszczenie finis poloniae”, czyli jak relacjonowano wybory parlamentarne... 2015 w polskich tygodnikach opinii, [w:] Jezyk a media. Wzory komunikacji we wspótczesnych mediach, red. B. Skowronek, E. Horyń, A. Walecka-Rynduch, Kraków 2018, https://doi.org/10.24917/9788380.

Brzoza K., Kornacka-Grzonka M., Narracja medialna wyrażona na oktadkach wybranych tygodników opinii podczas parlamentarnej kampanii wyborczej 2015 r., [online] http:// cejsh.icm.edu.pl/cejsh/element/bwmeta1.element.desklight-722d8789-c30f-4a87aa85-d9fb63a9 $1 \mathrm{fdb}$ ?q=bwmeta1.element.desklight-59ddb143-cde8-4d0d-a36657fbca99a6b7;7\&qt=CHILDREN-STATELESS, doi: 10.15584/polispol.2017.

Cwalina W., Falkowski A., Marketing polityczny. Perspektywa psychologiczna, Gdańsk 2005, Psychologia Polityczna.

Dobek-Ostrowska B., Komunikowanie polityczne i publiczne. Podręcznik akademicki, Warszawa 2012.

Dobek-Ostrowska B., Media masowe i aktorzy polityczni w świetle studiów nad komunikowaniem politycznym, Wrocław 2004, Acta Universitatis Wratislaviensis, nr 2594.

Entman R.M., Framing: Toward Clarification of a Fractured Paradigm, ,Journal of Communication" 1993, Vol. 43, nr 4, https://doi.org/10.1111/j.1460-2466.1993.tb01304.x.

Gamson W.A., Modigliani A., Media Discourse and Public Opinion on Nuclear Power: A Constructionist Approach, „American Journal of Sociology” 1989, Vol. 95, nr 1, https://doi.org/ $10.1086 / 229213$. 
Kunczik M., Zipfel A., Wprowadzenie do nauki o dziennikarstwie i komunikowaniu, przeł. J. Łoziński, W. Łukowski, Warszawa 2000.

Michalczyk S., Demokracja medialna. Teoretyczna analiza problemu, Toruń 2010, Oblicza Mediów.

Michalczyk S., Jednostka i spoteczeństwo w świecie mediów. Klasyczne i wspótczesne idee w teoriach średniego zasiegu, Katowice 2015.

Michalczyk S., Spoteczeństwo medialne. Studia z teorii komunikowania masowego, Katowice 2008.

Neuman W.R., Just M., Crigler A.N., Common Knowledge. News and the Construction of Political Meaning, Chicago 1992, American Politics and Political Economy Series, https://doi. org/10.7208/chicago/9780226161174.001.0001.

Nowak E., Riedel R., Agenda setting, priming, news framing. Analiza porównawcza telewizyjnych audycji informacyjnych TVN $i$ TVP1 w okresie kampanii przedwyborczych w Polsce 2005 i 2007, „Zeszyty Prasoznawcze” 2008, nr 1-2.

Palczewski M., Koncepcja framingu i jej zastosowanie w badaniach newsów w Wiadomościach TVP i Faktach TVN, „Studia Medioznawcze” 2011, nr 1.

Pfetsch B., Mayerhöffer E., Vordergründige Nähe. Zur Kommunikationskultur von Politik-und Medieneliten in Deutschland, "Medien \& Kommunikationswissenschaft” 2011, Vol. 59, nr 1, https://doi.org/10.5771/1615-634x-2011-1-40.

Piontek D., Komunikowanie polityczne i kultura popularna. Tabloidyzacja informacji o polityce, Poznań 2011.

Schulz W., Komunikacja polityczna. Koncepcje teoretyczne i wyniki badań empirycznych na temat mediów masowych w polityce, przeł. J. Kożuch, Kraków 2006, Media - Wydawnictwo Uniwersytetu Jagiellońskiego.

Semetko H.A., Valkenburg P.M., Framing European Politics: A Content Analysis of Press and Television News, "Journal of Communication” 2000, Vol. 50, nr 2, https://doi.org/ 10.1111/j.1460-2466.2000.tb02843.x.

Volkmer I., Framing Theory, [w:] Encyclopedia of Communication Theory, red. S.W. Littlejohn, K.A. Foss, Los Angeles 2009.

Vreese C.H., News Framing: Theory and Typology, „Information Design Journal \& Document Design”, 2005, Vol. 13, nr 1, https://doi.org/10.1075/idjdd.13.1.06vre.

„Do Rzeczy” 2015 (różne numery).

„Newsweek” 2015 (różne numery).

„Wprost” 2015 (różne numery).

„Polityka” 2015 (różne numery).

Dr Katarzyna BRZOZA-KOLORZ - doktor nauk społecznych w zakresie nauk o polityce, adiunkt w Instytucie Dziennikarstwa i Komunikacji Medialnej Uniwersytetu Śląskiego w Katowicach. Główne zainteresowania badawcze: kobieta w mass mediach, komunikowanie lokalne, komunikowanie masowe i polityczne. 